\title{
REGULATION OF APOPTOSIS BY IL-10 AND THE ASSOCIATION WITH STAT-1 SIGNALING MOLECULE IN DENDRITIC CELLS
}

\author{
Nguyen Thu Thuy ${ }^{1}$, Nguyen Thi Xuan ${ }^{2, *}$ \\ ${ }^{1}$ Institute of Biomedicine and Pharmacy, Vietnam Military Medical University Ha Noi, Vietnam \\ ${ }^{2}$ Institute of Genome Research, VAST, Vietnam
}

Received 1 June 2018, accepted 1 March 2019

\begin{abstract}
IL-10 is an anti-inflammatory cytokine, participating in induction of immune tolerance and cell apoptotic death. Dendritic cells (DCs) is the most professional antigen-presenting cells among innate immune cells to exert generation and maintenance of immunological memory mediated through activation of $\mathrm{T}$ and B lymphocytes. The STAT signalling pathway plays a regulatory role of maturation and differentiation of immune cells. In this study, DCs were treated with inflammatory cytokines including TNF- $\alpha$, INF $\gamma$, IL- 2 and IL-10 and subsequently examined the phosphorylation of STAT-1 and STAT-3, TNF- $\alpha$ concetration in cell suspension and the proportion of Annexin $\mathrm{V}^{+}$and caspase $3^{+}$cells. Methods used for this investigation include western blotting, flow cytometry and ELISA. DCs were derived from mouse bone marrow cells and cultured with GM-CSF for 8 days. As a result, IL-10, but not other cytokines enhanced the number of Annexin $\mathrm{V}^{+}$cells and caspase 3 activity in DCs. More importantly, IL-10 also increased the phosphorylation of STAT- 1 as well as the release of TNF- $\alpha$ into cell suspension. In conclusion, activation of STAT-1 might relate to the cell apoptotic death and TNF- $\alpha$ sectetion in IL-10-treated DCs.
\end{abstract}

Keywords: Apoptosis, dendritic cell, IL-10 and STAT.

Citation: Nguyen Thu Thuy, Nguyen Thi Xuan, 2019. Regulation of apoptosis of dendritic cells by IL-10 and in association with STAT-1 signaling molecule. Tap chi Sinh hoc, 41(1): 109-116. https://doi.org/10.15625/08667160/v41n1.12607.

*Corresponding author email: xuannt@igr.ac.vn

(C2019 Vietnam Academy of Science and Technology (VAST) 


\title{
VAI TRÒ ĐIỀU HÒA QUÁ TRÌNH APOPTOSIS CỦA IL-10 VÀ MỐI LIÊN Hệ VỚI TÍN HIÊU STAT-1 TRONG TẾ BÀO TUA
}

\author{
Nguyễn Thu Thủy ${ }^{1}$, Nguyễn Thị Xuân ${ }^{2, *}$ \\ ${ }^{1}$ Viện Nghiên cứu Y Dược học Quân sự, Học viện Quân y, Hà Nội, Việt Nam \\ ${ }^{2}$ Viện Nghiên cứu hệ gen, Viện Hàn lâm Khoa học và Công nghệ Việt Nam, Việt Nam
}

Ngày nhận bài 11-6-2018, ngày chấp nhận 1-3-2019

\section{TÓM TÁtT}

IL-10 là một cytokine kháng viêm tham gia tích cực vào trả lời miễn dịch đối kháng và quá trình apoptosis của tế bào. Tế bào tua (TBT) là tế bào trình diện kháng nguyên chuyên nghiệp nhất trong số các loại tế bào trong hệ thống miễn dịch không đặc hiệu, giúp hình thành trí nhớ miễn dịch thông qua hoạt hóa tế bào lympho $\mathrm{T}$ và $\mathrm{B}$. Tín hiệu phân tử STAT đóng vai trò điều hòa sự thuần thục và khả năng biệt hóa của tế bào miễn dịch. Trong nghiên cứu này, TBT được xử lý cùng các cytokine TNF- $\alpha$, INF $\gamma$, IL-2 và IL-10, tế bào sau khi thu hoạch được xác định sự phosphoryl hóa của protein STAT-1 và STAT-3, nồng độ TNF- $\alpha$ trong môi trường dịch huyền phù và số lượng tế bào phản ứng dương tính với các marker Annexin $\mathrm{V}$ và caspase 3 . Các phương pháp sử dụng trong nghiên cứu này bao gồm kỹ thuật western blotting, flow cytometry và ELISA. Vật liệu sử dụng là tế bào tủy xương chuột được nuôi cấy 8 ngày cùng hormone GMCSF. Kết quả nhận được cho thấy khi xử lý TBT cùng các loại cytokine trên, chỉ có IL-10 làm tăng mức độ biểu hiện của Annexin $\mathrm{V}$ và caspase 3 trong TBT, còn lại các cytokine khác không ảnh hưởng đến sự chết apoptosis của TBT. Hơn nữa, IL-10 làm tăng sự phosphoryl hóa của phân tử tín hiệu STAT-1 và tăng khả năng tiết TNF- $\alpha$ vào môi trường dịch huyền phù TBT. Kết quả nghiên cứu cho thấy tín hiệu phân tử STAT-1 có thể liên quan đến sự chết apoptosis và khả năng tiết TNF- $\alpha$ trong TBT xử lý cùng IL-10.

Từ khóa: Apoptosis, IL-10, STAT và tế bào tua.

*Địa chỉ liên hệemail: xuannt@igr.ac.vn

\section{MỞ ĐẦU}

Apoptosis là hoạt động bình thường trong quá trình phát triển và lão hóa của tế bào trong mô và các cơ quan trong cơ thể và là cơ chế phòng vệ của tế bào khi chúng bị tổn thương do bệnh lý hoặc tác nhân gây độc (Stephanou and Latchman, 2003). Tiến trình apoptosis đặc trưng bởi những thay đổi hình thái chính bao gồm mất tính gắn kết và bất đối xứng màng, cô đặc mất nước và sự co rút tế bào, mất điện sinh học màng ty thể và đứt gãy phân mảnh của nhiễm sắc thể trong nhân. Chính vì vậy, tế bào apoptosis có kích thước nhỏ hơn tế bào bình thường, không có khả năng tham gia vào các hoạt động sinh lý của cơ thể như sự tăng sinh và biệt hóa. Có hai con đường chính dẫn tới sự chết apoptosis được kết nối với nhau và có thể ảnh hưởng đến nhau là con đường ngoại bào phụ thuộc vào khả năng gắn với thụ thể trên bề mặt tế bào và con đường nội bào thông qua hoạt động của ty thể (Elmore, 2007).

Có nhiều yếu tố ảnh hưởng đến quá trình apoptosis của tế bào như phối tử toll-like receptor (TLR) và các loại cytokine viêm khác nhau (Simpson et al., 2016; Summan et al., 2018; Yoo et al., 2012). Một trong những phối tử TLR được nghiên cứu rộng 
rãi trên tế bào miễn dịch là phối tử TLR4 (lipopolysaccharide, LPS). Sự gắn kết giữa phối tử này và thụ thể TLR4 trong tế bào kích hoạt các tín hiệu phân tử hoạt động làm tăng tiết các cytokine như $T N F-\alpha$ và $I N F \gamma$ và giảm tiết IL-10 (Zhang and Zheng, 2005), dẫn tới ức chế hoạt động apoptosis của tế bào (Summan and Nejsum, 2018). Khả năng tiết các cytokine gây viêm của tế bào liên quan trực tiếp đến hoạt động miễn dịch của cơ thể, từ đó điều hòa quá trình trả lời miễn dịch hoặc trả lời đối kháng hoặc dị ứng, khi cơ thể tiểp xúc với các yếu tố gầy bệnh hoặc các tác nhân khác từ môi trường sống (Banchereau et al., 2000; Elmore, 2007). Trong số các loại cytokine viêm, IL-10 là cytokine kháng viêm tham gia kích thích hoạt động của hệ miễn dịch đối kháng và được biết đến như một yếu tố cảm ứng quá trình apoptosis trên một số tế bào khác nhau (Simpson and Miles, 2016; Summan and Nejsum, 2018; Yoo and Byun, 2012). Các loại cytokine tiền viêm như IL-2 và $\mathrm{TNF}-\alpha$ là những nhân tố kích hoạt sự chết apoptosis của nhiều loại tế bào khác nhau (Cerezo et al., 1999; Kim et al., 2018; Zhao et al., 2018). Vai trò của hai loại cytokine kháng viêm và tiền viêm đóng vai trò đối kháng nhau để duy trì cân bằng nội môi trong cơ thể (Summan and Nejsum, 2018; Yoo and Byun, 2012). Một số nghiên cứu gần đây cho thấy ảnh hưởng ngược lại của $\mathrm{IL}-10$ đóng vai trò ức chế apoptosis trong tế bào phôi thai bởi làm tăng biểu hiện của protein $\mathrm{Bcl}-2$ trong ty thể (Wang et al., 2015) hoặc trong tế bào T điều hòa ở bệnh nhân viêm khớp (Li et al., 2014). Hoạt động của tế bào $\mathrm{T}$ điều hòa liên quan đến sự trả lời miễn dịch đối kháng trong cơ thể (Banchereau and Briere, 2000).

Tế bào tua (TBT) là tế bào trình diện kháng nguyên chuyên nghiệp nhất tới tế bào lympho $\mathrm{T}$ trong đáp ứng miễn dịch đặc hiệu chống lại bệnh tật. TBT đóng vai trò quan trọng kích hoạt đáp ứng miễn dịch bẩm sinh, cảm ứng sự trả lời của đáp ứng miễn dịch thu được và hình thành trí nhớ miễn dịch thông qua sự tăng biểu hiện của các phân tử đồng kích thích và phân tử tương thích mô chính và giải phóng ra các cytokine viêm (Banchereau and Briere, 2000). Cùng với các hoạt động sinh lý của TBT như sự tăng sinh, sự biệt hoá, di cư, thực bào thì quá trình apoptosis cũng đóng vai trò quan trọng trong việc kiểm soát sự cân bằng số lượng tế bào trong cơ thể. TBT là một trong những tế bào trong hệ miễn dịch bẩm sinh đóng vai trò quan trọng trong việc chéo lái sự trả lời của hệ miễn dịch thông qua khả năng tiết các cytokine gây viêm và cytokine kháng viêm, từ đó cảm ứng sự chết apoptosis hoặc ức chế quá trình này thông qua các tín hiệu hoạt hóa kích hoạt các tê bào miễn dịch khác hoạt động (Banchereau and Briere, 2000; Elmore, 2007).

Có nhiều tín hiệu phân tử bên trong tế bào tham gia cảm ứng/ức chế sự chết apoptosis khi tế bào tiếp xúc với các cytokine viêm bởi hoạt động cảm ứng sự phiên mã các gen liên quan đến apoptosis và biểu hiện các protein liên quan đến hoạt động sinh trưởng và phát triển của tế bào (Elmore, 2007; Stephanou and Latchman, 2003; Yoo and Byun, 2012). Một trong những tín hiệu phân tử liên quan đến quá trình apoptosis được biết đến là tín hiệu STAT (the signal transducers and activators of transcription), tín hiệu này được kích hoạt thông qua sự phosphoryl hóa vùng $\mathrm{C}$-terminal (Stephanou and Latchman, 2003). Nghiên cứu trước đó đã cho thấy rằng tín hiệu STAT tham gia điều hòa mức độ thuần thục và sự biệt hóa của tế bào miễn dịch không đặc hiệu (Kotthoff et al., 2017). Trong đó, STAT-1 cũng được chỉ ra có liên quan đến việc điều chỉnh các gen điều hòa quá trình apoptosis và ức chế sự phát triển của khối u, những con chuột thiếu hụt gen STAT-1 xuất hiện các khối u tự phát nhanh hơn so với nhóm đối chứng (Stephanou and Latchman, 2003).

Các nghiên cứu về quá trình apoptosis của TBT khi tế bào này tiếp xúc với các loại cytokine như TNF- $\alpha$, INF $\gamma$, IL-2 và IL-10 và các tín hiệu phân tử liên quan STAT-1 và STAT-3 ít được biết đến, chính vì thế, chúng tôi thực hiện các thí nghiệm xác định mức độ hoạt động của các phân tử tín hiệu STAT-1 và STAT-3 và số lượng tế bào phản ứng dương tính với các marker annexin $\mathrm{V}$ và caspase 3 để chỉ ra vai trò của các loại cytokine này tác động tới sự chết apoptosis trong TBT. 


\section{VÂT LIÊU VÀ PHƯƠNG PHÁP NGHIÊN} CỨU

Chuột BALB/c mice được mua từ công ty Taconic Farms (Hudson, NY, USA) và được nuôi trong điều kiện sạch, không nhiễm khuẩn tại Viện Nghiên cứu hệ gen, Viện Hàn lâm Khoa học và Công nghệ Việt Nam.

\section{Nuôi cấy và biệt hóa tế bào tua}

Tế bào tủy xương chân sau của chuột được rửa sạch bằng PBS (phosphate-buffered saline), diệt tế bào hồng cầu và rửa lại bằng môi trường nuôi cấy (MTNC: Gồm có môi trường RPMI $1640+10 \%$ FBS (fetal bovine serum) $+1 \%$ glutamine $+50 \mu \mathrm{M} \beta-$ mercaptoethanol $+1 \%$ penicillin/ Streptomycin). Sau đó, tế bào tủy xương được đem nuôi cấy trong tủ ấm với điều kiện nuôi cấy ở $37^{\circ} \mathrm{C}, 5 \% \mathrm{CO}_{2}$ cùng với hormone GMCSF (granulocyte-macrophage colonystimulating factor, $35 \mathrm{ng} / \mathrm{ml}$ ) trong vòng 8 ngày. Cứ 3 ngày các tế bào được thay MTNC mới có thêm hormone GM-CSF $(35 \mathrm{ng} / \mathrm{ml})$. Sau 8 ngày nuôi cấy, các tế bào được thu hoạch, rửa sạch và phân tích phần trăm $(\geq$ $85 \%$ ) tế bào tủy xương biệt hóa thành TBT. Tế bào này được xử lý trước với kháng nguyên LPS và sau đó xử lý với các loại cytokine khác nhau bao gồm TNF- $\alpha$ (10ng/ml, Sigma), INF- $\gamma \quad(10 \mathrm{ng} / \mathrm{ml}$, Sigma $), \quad$ IL-2 (30 ng/ml, Sigma), và IL-10 (20 ng/ml hoặc 200 ng/ml, Sigma).

\section{Thí nghiệm xác đinh tế bào dương tính với} Annexin V bằng kỹ thuật flow cytometry

TBT được hoạt hóa bởi kháng nguyên LPS trước 1 giờ và sau đó xử lý cùng các cytokine TNF- $\alpha$, INF- $\gamma$, IL-2 và IL-10 $(20 \mathrm{ng} / \mathrm{ml}$ hoặc $200 \mathrm{ng} / \mathrm{ml})$ trong 24 giờ. Sau đó, TBT được nhuộm với $100 \mu \mathrm{l}$ dung dịch FACS buffer (bao gồm PBS và $0,1 \%$ FBS) có chứa kháng thể gắn huỳnh quang ở nồng độ $10 \mu \mathrm{g} / \mathrm{ml}$. Hóa chất sử dụng trong nghiên cứu này bao gồm kháng thể FITC anti-annexin $\mathrm{V}$ và 7-amino-actinomycin $\mathrm{D}$ (7-AAD). Tế bào được nhuộm với các hóa chất trên trong 45 phút ở $4^{\circ} \mathrm{C}$, sau đó đem rửa sạch hai lần và tái hòa tan bằng dung dịch đệm FACS. Khoảng 2 $\times 10^{4}$ TBT trong mỗi ống nghiệm được sử dụng để phân tích tỷ lệ phần trăm số tế bào dương tính với chỉ thị Annexin $\mathrm{V}$ và âm tính với chỉ thị 7-AAD bằng kỹ thuật flow cytometry sử dụng máy FACS CantoII.

\section{Thí nghiệm đo hoạt động caspase 3 bằng kỹ thuật flow cytometry}

TBT được hoạt hóa bởi kháng nguyên LPS trước 1 giờ và sau đó xử lý cùng các cytokine TNF- $\alpha$, INF- $\gamma$, IL-2 và IL-10 ( $20 \mathrm{ng} / \mathrm{ml}$ hoặc $200 \mathrm{ng} / \mathrm{ml}$ ) trong 24 giờ. Hoạt động của caspase 3 được xác định sử dụng bộ kít hóa chất từ công ty Biovision theo hướng dẫn của nhà sản xuất. $10^{6} \mathrm{TBT}$ được rửa hai lần bằng $\mathrm{PBS}$ lạnh, cố định bằng dung dịch "Cytofix/Cytoperm" và sau đó rửa hai lần bằng đệm "Perm/Wash". Sau đó, các tế bào được nhuộm với kháng thể FITC anti-caspase 3 trong đệm "Perm / Wash" trong 60 phút. Sau hai bước rửa, các tế bào được phân tích bằng phép đo tế bào dòng chảy flow cytometry.

\section{Phân tích nồng độ TNF- $\alpha$ trong dịch huyền phù bằng kỹ thuật ELISA}

TBT được hoạt hóa bởi kháng nguyên LPS trước 1 giờ và sau đó xử lý cùng cytokine IL-10 $(200 \mathrm{ng} / \mathrm{ml})$ trong 4 giờ. Sau nuôi cấy, dịch huyền phù của tế bào được thu thập và trữ đông ở $-20^{\circ} \mathrm{C}$ cho đến khi phân tích nồng độ cytokine bằng kỹ thuật ELISA. Để đo nồng độ TNF- $\alpha$ trong dịch huyền phù chúng tôi sử dụng kít thương mại mouse TNF- $\alpha$ ELISA Ready-SET-Go (eBioscience), cách làm dựa trên những hướng dẫn cụ thể của công ty.

\section{Điện di protein bằng kỹ thuật Western blotting}

TBT được hoạt hóa bằng kháng nguyên LPS trước 1 giờ và sau đó xử lý cùng cytokine IL-10 $(200 \mathrm{ng} / \mathrm{ml})$ trong 4 giờ, sau đó phá vỡ tế bào bằng dung dịch RIPA buffer (Sigma Aldrich) để thu được protein tổng số. Mẫu protein được điện di biến tính trên gel SDSPAGE 10\%, sử dụng màng PVDF (polyvinylidene fluoride) để chuyển protein từ bản gel sang màng. Sau đó, màng được phủ bằng dung dịch $5 \%$ skim milk + TBS-T (bao gồm TBS và $0,01 \%$ tween 20 ) trong 2 giờ, rửa màng 3 lần với TBS-T trong 30 phút. Tiếp theo ủ màng với kháng thể sơ cấp bao gồm 
kháng thể phospho-STAT-1, phospho-STAT3 và anti-GAPDH (Santa Cruz) ở $4^{\circ} \mathrm{C}$ qua đêm và rửa lại 3 lần với TBS-T trong 30 phút. Màng tiếp tục được ủ với kháng thể thứ cấp gắn với enzyme $\mathrm{HRP}$ (GE Healthcare) pha trong dung dịch 5\% skim milk + TBS-T trong 1 giờ ở nhiệt độ thường, sau đó rửa màng 3 lần trong 30 phút với dung dịch TBS-T. Protein được phát hiện bằng dung dịch hiện màu ECL Plus kit (GE Healthcare).

\section{Phương pháp xử lý số liệu}

Kết quả thí nghiệm là trung bình cộng của các giá trị và được xử lý bằng phương pháp unpaired Student $t$-test. Các nghiên cứu được lặp lại ít nhất 3 lần. Sự khác biệt giữa mẫu đối chứng và mẫu được xử lý có ý nghĩa thống kê khi chỉ số $\mathrm{p}$ value $<0,05$.

\section{KẾT QUẢ VÀ THẢO LUẬN}

\section{Phân tích số lượng tế bào phản ứng dương tính với marker Annexin $\mathrm{V}$}

Annexin $\mathrm{V}$ là một thành viên của họ protein nội bào gắn với phosphatidyl serine (PS) trên bề mặt tế bào theo cách phụ thuộc vào canxi. Thông thường $\mathrm{PS}$ chỉ được tìm thấy ở bên trong màng của tế bào khoẻ. Khi tế bào bị tôn thương ở giai đoạn sớm, màng mất đi tính đối xứng và PS chuyển vị trí ra ngoài bề mặt tế bào. PS có thể tương tác với kháng thể Annexin $\mathrm{V}$ nên kháng thể này được dùng để xác định số lượng tế bào biểu hiện PS, tuy nhiên phương pháp này không phân biệt được tế bào apoptosis và necrosis (Xuan et al., 2010). Vì vậy, việc kết hợp với hóa chất huỳnh quang 7-AAD để nhuộm nhân tế bào được sữ dụng trong thí nghiệm này. 7-AAD là một hợp chất hoá học có ái lực mạnh với DNA vì vậy được dùng để đếm số lượng tế bào bị chết necrosis bằng thiết bị flow cytometry. Các tế bào apoptosis hoặc tế bào sống có màng nhân nguyên vẹn sẽ thải loại 7$\mathrm{AAD}$, trong khi các tế bào necrosis bị tổn thương màng nhân sẽ bị nhuộm DNA (Xuan \& Shumilina, 2010).

TBT được tạo ra từ sự biệt hóa tế bào tủy xương sau 8 ngày được xử lý trước 1 giờ cùng LPS, sau đó xử lý tiếp trong 24 giờ cùng với các loại cytokine khác nhau bao gồm TNF- $\alpha$, INF- $\gamma$, IL-2 và IL-10 (20 ng/ml hoặc $200 \mathrm{ng} / \mathrm{ml}$ ). Các tế bào được nhuộm cùng kháng thể FITC anti-annexin $\mathrm{V}$ và hóa chất huỳnh quang 7-AAD. Nghiên cứu phân tích phần trăm số tế bào phản ứng dương tính với kháng thể annexin $\mathrm{V}$ và âm tính với $7-\mathrm{AAD}$, chúng tôi đã chỉ ra được rằng so với nhóm tế bào đối chứng thì chỉ có nhóm tế bào được xử lý bằng $\mathrm{IL}-10$ ở nồng độ $200 \mathrm{ng} / \mathrm{ml}$ tăng số lượng tế bào phản ứng dương tính với Annexin $\mathrm{V}$ một cách rõ ràng, còn các cytokine còn lại không ảnh hưởng đến tỷ lệ tế bào chểt apoptosis, bao gồm nhóm xử lý bằng IL-10 ở nồng độ thấp hơn $(20 \mathrm{ng} / \mathrm{ml})$, các nhóm xử lý lần lượt bằng $\mathrm{TNF}-\alpha, \mathrm{INF}-\gamma$ và $\mathrm{IL}-2$ (hình 1 ).
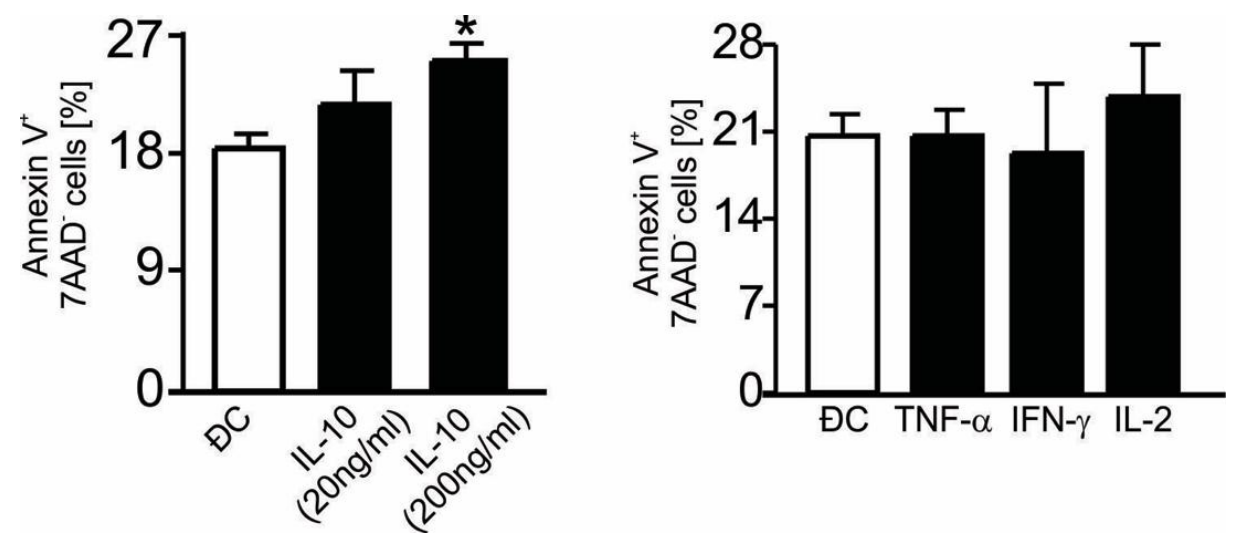

Hình 1. Phân tích tỷ lệ tế bào phản ứng dương tính với marker annexin $\mathrm{V}$ dưới tác động của cytokine IL-10, IL-2, TNF- $\alpha$ và INF- $\gamma(\mathrm{n}=4-5)$ * $(\mathrm{p}<0,05)$ chỉ ra sự khác biệt có ý nghĩa thống kê giữa nhóm đối chứng và nhóm tể bào được xử lý cùng IL-10

(phân tích kết quả bằng hàm ANOVA) 
Phân tích số lượng tế bào phản ứng dương tính với marker caspase 3

Caspase-3 là protein được mã hoá bởi gen $C A S P 3$, là thành viên của nhóm protease cysteine-aspartic acid tham gia vào quá trình phân mảnh DNA (McArthur \& Kile, 2018). Hoạt động của caspase tác động xấu tới ty thể làm mất điện màng sinh học ty thể, không cung cấp đủ năng lượng cho tế bào dẫn tới sự chết necrosis của tế bào. Trong nghiên này, chúng tôi phân tích số lượng tế bào phản ứng dương tính với kháng thể huỳnh quang caspase 3 bằng kỹ thuật flow cytometry. Dựa vào mật độ tế bào phát huỳnh quang, từ đó xác định được phần trăm số tế bào biểu hiện hoạt động caspase 3 .

Tượng tự như trên, TBT được tạo ra từ sự biệt hóa tế bào tủy xương sau 8 ngày được xử lý trước 1 giờ cùng LPS, sau đó xử lý tiếp trong 24 giờ cùng với các loại cytokine khác nhau bao gồm TNF- $\alpha$, INF- $\gamma$, IL-2 và IL-10 $(20 \mathrm{ng} / \mathrm{ml}$ hoặc $200 \mathrm{ng} / \mathrm{ml})$. Kết quả chỉ ra rằng, so với nhóm tế bào đối chứng thì nhóm tế bào được xử lý bằng IL-10 ở nồng độ $200 \mathrm{ng} / \mathrm{ml}$ tăng biểu hiện caspase 3 hoạt động, còn lại các nhóm khác được xử lý bằng TNF- $\alpha, \mathrm{INF}-\gamma$, IL-2 và $\mathrm{IL}-10$ $(20 \mathrm{ng} / \mathrm{ml})$ biểu hiện hoạt động của caspase 3 không khác biệt rõ ràng (hình $2 \mathrm{~A}-2 \mathrm{C}$ ).
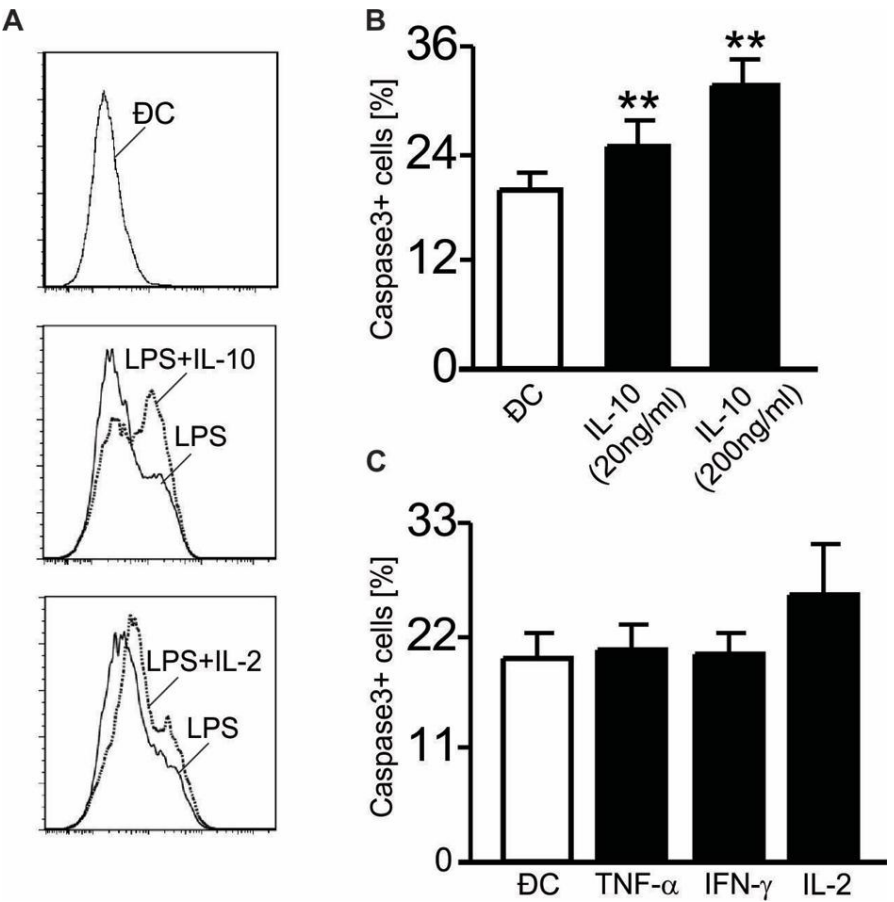

Hình 2. Phân tích tỷ lệ tế bào phản ứng dương tính với marker caspase 3 dưới tác động của cytokine IL-10, IL-2, TNF- $\alpha$ và INF- $\gamma$. A: Hình histogram biểu hiện hoạt động của caspase 3 dưới ảnh hưởng của IL-10 (200 ng/ml) hoặc IL-2 trong các TBT trưởng thành. B-C: Tỷ lệ tế bào phản ứng dương tính với marker caspase 3 dưới tác động của cytokine IL-10, IL-2, TNF- $\alpha$ và INF- $\gamma(\mathrm{n}=4-5)$.** $(\mathrm{p}<0,01)$ chỉ ra sự khác biệt có ý nghĩa thống kê giữa nhóm đối chứng và nhóm tế bào được xử lý cùng IL-10 (phân tích kết quả bằng hàm ANOVA)

Phân tích hoạt động của tín hiệu phân tử STAT1 và STAT3 bằng kỹ thuật western blotting

Hoạt động của tín hiệu phân tử STAT tác động tới quá trình phiên mã và chuyển dịch các gen chức năng từ tế bào chất vào nhân, từ đó điều hòa các quá trình sinh lý của cơ thể. Tín hiệu hoạt động của phân tử STAT được chỉ ra liên quan đến quá trình tăng sinh, thuần thục, biệt hóa và sự chết apoptosis của tế bào (Bai et al., 2018, Stephanou \& Latchman, 2003). 
Trong nghiên cứu này, TBT được xử lý trước 1 giờ cùng LPS, sau đó xử lý tiếp trong 4 giờ cùng $\mathrm{IL}-10(200 \mathrm{ng} / \mathrm{ml})$. Tế bào được phá vỡ bằng dung dich RIPA thu được protein tông số, sau đó protein được điện di để xác định biểu hiện hoạt động của tín hiệu phân tử STAT-1 và STAT-3. Kết quả chỉ ra rằng, hoạt hóa $\mathrm{TBT}$ bằng kháng nguyên LPS hoặc IL-10 cùng làm tăng sự phosphoryl hóa của STAT-1 và hoạt động của tín hiệu này tăng hơn nữa khi tế bào được xử lý cùng với LPS và IL-10. Hoạt động của tín hiệu STAT-3 không thay đổi khi tế bào được xử lý cùng IL-10 (hình 3).

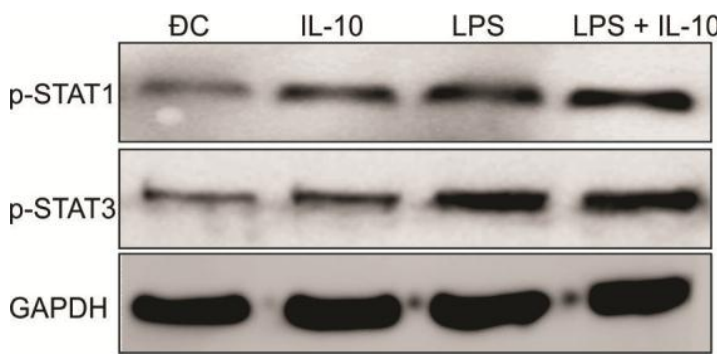

Hình 3. Phân tích tín hiệu hoạt động STAT-1 và STAT3 trong TBT $(\mathrm{n}=3)$

Phân tích khả năng tiết TNF- $\alpha$ trong dịch huyền phù TBT bằng kỹ thuật ELISA

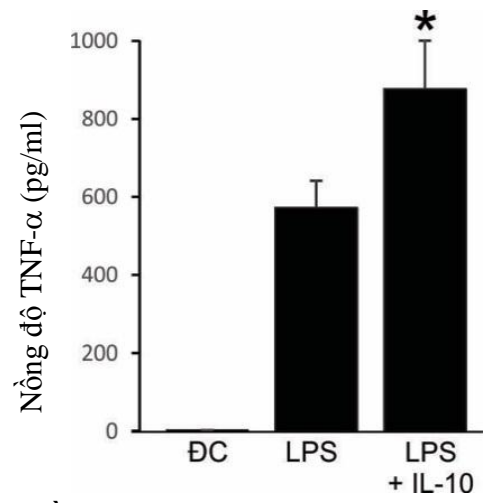

Hình 4. Nồng độ của TNF- $\alpha$ trong dịch huyền phù TBT đo bằng kỹ thuật ELISA $(\mathrm{n}=5)$. *(p $<0,05)$ chỉ ra sự khác biệt có ý nghĩa thống kê giữa nhóm đối chứng và nhóm tế bào được xử lý cùng IL-10 (phân tích kết quả bằng hàm ANOVA)

Thông thường, khi kích hoạt TBT bằng kháng nguyên LPS làm tăng tiết các loại cytokine viêm từ đó ức chế sự chết apoptosis của tế bào. Ngược lại, khi tế bào chết necrosis, khả năng giải phóng các loại cytokine viêm giảm đi do vật chất di truyền trong nhân tế bào bị thoái hóa. Trong nghiên cứu này, TBT được xử lý trước 1 giờ cùng LPS, sau đó xử lý tiếp trong 4 giờ cùng $\mathrm{IL}-10(200 \mathrm{ng} / \mathrm{ml})$ và cuối cùng thu hoạch dịch huyền phù cho thí nghiệm xác định nồng độ TNF- $\alpha$ bằng kỹ thuật ELISA. Nồng độ TNF- $\alpha$ thu được nhiều hơn trong môi trường nuôi cấy tế bào cùng IL-10 đã cho thấy rằng sự phosphoryl hóa của STAT-1 dẫn tới làm tăng sự phiên mã của gen TNF- $\alpha$ trong nhân tế bào (hình 4). Chính vì thế, IL-10 làm chết apoptosis TBT có thể liên quan đến tín hiệu hoạt động gây chết tế bào dòng trên TNF/TNF receptor (Jaeschke \& Woolbright, 2013).

\section{KẾT LUẬN}

Trong nghiên cứu này, chúng tôi chỉ ra lần đầu tiên về vai trò của IL-10 cảm ứng sự chết apoptosis trên TBT chuột xuất phát từ tế bào tủy xương và các cytokine khác như IL-2, TNF- $\alpha$ và INF- $\gamma$ không ảnh hưởng tới sự chết apoptosis của tế bào này. Quan trọng hơn, chúng tôi cũng chỉ ra biểu hiện của tín hiệu STAT-1 và sản phẩm tiết TNF- $\alpha$ tăng lên khi tế bào được xử lý cùng IL-10. Chính vì thế, IL-10 làm tăng tiết TNF- $\alpha$ thông qua tín hiệu hoạt động của phân tử STAT-1 và dẫn tới sự chết apoptosis trong TBT.

Lòi cám ơn: Công trình hoàn thành với kinh phí được tài trợ bởi đề tài "Nghiên cứu vai trò điều hòa của gen mã hóa cho protein $\mathrm{A} 20$ với bệnh bạch cầu cấp tính và các cơ chế phân tử tham gia kiểm soát quá trình sinh lý tế bào" của Quỹ Phát triển Khoa học và Công nghệ Quốc gia (NAFOSTED) số 108.06-2017.16.

\section{TÀI LIỆU THAM KHẢO}

Bai L., Fang H., Xia S., Zhang R., Li L., Ochando J., Xu J., Ding Y., 2018. STAT1 activation represses IL-22 gene expression and psoriasis pathogenesis. Biochem. Biophys. Res. Commun., 501: 563-569.

Banchereau J., Briere F., Caux C., Davoust J., Lebecque S., Liu Y. J., Pulendran B., 
Palucka K., 2000. Immunobiology of dendritic cells. Annu. Rev. Immunol., 18: 767-811.

Cerezo A, Martinez, A. C, Gonzalez A., Gomez J., RebolloA., 1999. IL-2 deprivation triggers apoptosis which is mediated by c-Jun N-terminal kinase 1 activation and prevented by Bcl-2. Cell Death Differ., 6: 87-94.

Elmore S., 2007. Apoptosis: a review of programmed cell death. Toxicol Pathol., 35: 495-516.

Jaeschke, H., \& Woolbright, B. L. (2013). Role of heme oxygenase 1 in TNF/TNF receptor-mediated apoptosis after hepatic ischemia/reperfusion in rats. Shock 39: 380-388, 2013. Shock (Augusta, Ga.)., 40(1): 75-76.

Kim Y. A., Kim H. Y., Oh Y. J., Kwon W. Y., Lee M. H., Bae J. Y., Woo M. S., Kim J. M., \& Yoo Y. H., 2018. Polychlorinated biphenyl 138 exposure-mediated lipid droplet enlargement endows adipocytes with resistance to TNF-alpha-induced cell death. Toxicol Lett., 292: 55-62.

Kotthoff P., Heine A., Held S. A. E., Brossart P., 2017. Dexamethasone induced inhibition of Dectin-1 activation of antigen presenting cells is mediated via STAT-3 and NF-kappaB signaling pathways. Sci Rep., 7: 4522.

Li N., Ma T., Han J., Zhou J., Wang J., Zhang J., Zheng S., 2014. Increased apoptosis induction in CD4+ CD25+ Foxp3+ T cells contributes to enhanced disease activity in patients with rheumatoid arthritis through IL-10 regulation. Eur. Rev. Med. Pharmacol. Sci., 18: 78-85.
McArthur K., Kile B. T., 2018. Apoptotic Caspases: Multiple or Mistaken Identities? Trends Cell Biol., 28: 475-493.

Simpson J., Miles K., Trub M., MacMahon R., Gray M., 2016. Plasmacytoid Dendritic Cells Respond Directly to Apoptotic Cells by Secreting Immune Regulatory IL-10 or IFN-alpha. Front. Immunol., 7: 590.

Stephanou, A. and Latchman, D. S. 2003. STAT-1: a novel regulator of apoptosis. Int. J. Exp. Pathol., 84: 239-44.

Summan, A.; Nejsum, P.and Williams, A.R. 2018. Modulation of human dendritic cell activity by Giardia and helminth antigens. Parasite Immunol., 40: e12525.

Wang A.; Liu Q., Zhang J., Zheng R., 1 2015. Berberine alleviates preeclampsia possibly by regulating the expression of interleukin-2/interleukin-10 and Bcl2/Bax. Int. J. Clin. Exp. Med., 8: 16301-7.

Xuan, N. T., Shumilina E., Gulbins E., Gu S., Gotz F., Lang F., 2010. Triggering of dendritic cell apoptosis by xanthohumol. Mol. Nutr. Food. Res. 54 Suppl., 2: S214-24.

Yoo H. J., Byun H. J., Kim B. R., Lee, K. H., Park S. Y., Rho S. B., 2012. DAPk1 inhibits NF-kappaB activation through TNF-alpha and INF-gamma-induced apoptosis. Cell Signal, 24: 1471-7.

Zhang W. J., Zheng S. S., 2005. In vitro study of immunosuppressive effect of apoptotic cells. J. Zhejiang Univ. Sci., B 6: 919-25.

Zhao S., Feng J., Wang Q., Tian, L., Zhang Y. \& Li H., 2018. hnRNP $\mathrm{K}$ plays a protective role in TNF-alpha-induced apoptosis in podocytes. Biosci. Rep., 38: $1-10$. 